\title{
Influence of Modified Atmosphere Packaging on the Survival of Salmonella Enteritidis PT 8 on the Surface of Chilled Chicken Legs
}

\author{
Radka Hulánková, Gabriela Bořilová, Iva Steinhauserová \\ Department of Meat Hygiene and Technology, Faculty of Veterinary Hygiene and Ecology, University of \\ Veterinary and Pharmaceutical Sciences Brno, Czech Republic
}

Received June 24, 2009

Accepted June 15, 2010

\begin{abstract}
The aim of this study was to find whether low numbers of Salmonella in the presence of natural microflora will survive on the surface of chicken legs stored in $30 \% \mathrm{CO}_{2} / 70 \% \mathrm{~N}_{2}$ and $20 \%$ $\mathrm{CO}_{2} / 80 \% \mathrm{O}_{2}$. In four experiments, a total of 240 pieces of chicken leg were inoculated with a Salmonella Enteritidis, PT 8, wildtype strain resulting in initial concentrations of approximately $4 \mathrm{log}, 2.5 \mathrm{log}, 1.5 \mathrm{log}$ and $0.5 \mathrm{log}$ cells per piece and kept under selected modified atmospheres for 14 days. Counts of Salmonella were determined by the Most Probable Number method (MPN) at days $0,3,7,10$ and 14 of storage. No significant increase or decrease in Salmonella numbers was observed in the atmosphere of $20 \% \mathrm{CO}_{2} / 80 \% \mathrm{O}_{2}$. In the atmosphere of $30 \% \mathrm{CO}_{2} / 70 \% \mathrm{~N}_{2}$ there was a significant decrease in cell numbers at days 10 and 14; however, this decrease was proved only in experiments with an initial Salmonella concentration of $4 \log$ and $1.5 \mathrm{log}$ cells per piece. We proved that even low numbers of $S$. Enteritidis in the presence of natural microflora survive well on the surface of poultry stored at $3{ }^{\circ} \mathrm{C}$ in both modified atmospheres we tested. In the case of temperature abuse even products with low initial numbers of Salmonella may constitute a health risk for consumers.
\end{abstract}

Enumeration, Enteritidis, chicken legs, MPN, MAP

Poultry meat is very popular among consumers, though it is also the type of meat with the highest risk of the presence of Salmonella. In addition to eggs and egg products, poultry meat and poultry meat products are considered one of the main sources of salmonellosis, the incidence of which in the Czech Republic is continually one of the highest in the European Union. The most commonly identified causative agent of salmonellosis, as well as the most commonly isolated Salmonella serotype in poultry meat, is Salmonella Enteritidis (EFSA, 2009).

Salmonella contamination of poultry meat at the slaughterhouse can be caused by faeces released from the alimentary tract of birds colonised with Salmonella, followed by crosscontamination resulting in the spread of bacteria to previously uncontaminated carcasses during processing. The processing operations including final spray-washing and chilling cannot completely remove the Salmonella from the surface of the carcasses (Mead 2004; Olsen et al. 2003; Rasschaert et al. 2007). Some Salmonella strains can survive in the slaughter environment for up to 5 days despite daily cleaning and disinfection procedures (Olsen et al. 2003) and results of studies using genotyping methods indicate that not only the currently slaughtered birds but also the slaughter environment can be an important source of poultry meat contamination (Rasschaert et al. 2007).

The reported prevalences of Salmonella spp. on broiler carcasses after chilling range widely, reaching several tens of percents in some cases (FAO/WHO 2002) depending, for example, on the presence/absence of Salmonella within the slaughtered flock, the processing technologies used, the effectiveness of cleaning and washing at the slaughterhouse, and the microbiological methods used for Salmonella detection. Unlike another important pathogen Campylobacter spp., the numbers of Salmonella in poultry are generally not very high. Although Salmonella enumeration is not usually performed, in most of the studies

Address for correspondence:

Mgr. Radka Hulánková

Dept. of Meat Hygiene andTechnology

University of Veterinary and Pharmaceutical Sciences

Palackého 1-3

Phone: + 420541562747

61242 Brno, Czech Republic

E-mail: h06294@vfu.cz

http://www.vfu.cz/acta-vet/actavet.htm 
conducted so far the Salmonella counts have not exceeded $2 \log$ MPN/carcass, rarely $4 \log$ MPN/carcass (FAO/WHO 2002; Mead 2004).

One of the most important aspects in poultry meat production in addition to safety is shelf life. Both these indicators can be affected positively by modified atmosphere packaging (MAP) in combination with low storage temperature $\left(<4^{\circ} \mathrm{C}\right)$ (Phillips 1996). Because of the quick turnover time in the retail marketing of poultry meat and the extra costs of MAP, modified atmosphere packaging has not been frequently employed recently; however, from an economical and public health point of view, interest among producers is increasing (Bolder 2007).

The most frequent gaseous mixtures used for poultry packaging are $100 \% \mathrm{CO}_{2}$ and 25 $30 \% \mathrm{CO}_{2} / 70-75 \% \mathrm{~N}_{2}$ or $20-40 \% \mathrm{CO}_{2} / 60-80 \% \mathrm{O}_{2}$ (Phillips 1996). All these mixtures take advantage of the antimicrobial effect of carbon dioxide manifested at concentrations above $10 \%$ (Floros and Matsos 2005). $\mathrm{A} \mathrm{CO}_{2}$ concentration of $20-40 \%$ is generally used, as concentrations under $15 \%$ do not inhibit microbial growth sufficiently, whereas concentrations above $40 \%$ can lead to the collapse of packages due to $\mathrm{CO}_{2}$ absorption by meat tissue (McMillin 2008).

Carbon dioxide inhibits the growth of aerobic microorganisms by prolongation of the lag phase and generation time during the logarithmical phase of growth (Floros and Matsos 2005). Gram-negative bacteria are generally more sensitive to carbon dioxide than Grampositive bacteria, which are mostly facultatively or strictly anaerobic (McMillin 2008). Increased levels of carbon dioxide also inhibit the growth of Enterobacteriaceae, including that of Salmonella (Floros and Matsos 2005; Phillips 1996).

It is well known that the amount of dissolved carbon dioxide and its antimicrobial effect increase as storage temperature decreases. Although Salmonella spp. should not be able to multiply at the temperatures under $4{ }^{\circ} \mathrm{C}$ used for poultry meat storage according to the requirements of the legislation, cases of Salmonella growth in poultry meat at $2{ }^{\circ} \mathrm{C}$ have been reported (D'Aoust 1991). Many predictive models for Salmonella growth in poultry meat have been developed. Nevertheless, none of them is applicable for temperatures under $4{ }^{\circ} \mathrm{C}$ (FAO/WHO 2002).

Even low numbers of Salmonella can constitute a risk for consumers when temperature abuse occurs in the commercial chain allowing the bacteria to multiply, and in the case of inadequate thermal processing. The aim of this study was, therefore, to find out whether even low numbers of Salmonella in the presence of natural microflora on the surface of chicken legs will survive storage in $30 \% \mathrm{CO}_{2} / 70 \% \mathrm{~N}_{2}$ and $20 \% \mathrm{CO}_{2} / 80 \% \mathrm{O}_{2}$.

\section{Materials and Methods}

\section{Chicken legs}

A total of 240 pieces of chicken legs of the same weight category (average weight about $250 \mathrm{~g}$ ) were obtained from a local poultry slaughterhouse. The chicken legs originating from a ROSS 308 broiler line were taken at the end of the slaughter line after chilling and transported at a temperature below $+3{ }^{\circ} \mathrm{C}$ to the laboratory for immediate processing. For each combination of concentration and modified atmosphere a separate experiment with 30 chicken legs was performed.

\section{Testing strain and preparation of inoculum}

For inoculation we used a strain of Salmonella enterica subsp. enterica ser. Enteritidis, phagotype PT 8 (wildtype), isolated from poultry meat and provided by the National Institute of Public Health Brno. The inoculum was prepared from cells in the stationary phase of growth, obtained from a 24-h-old culture grown on blood agar at $37^{\circ} \mathrm{C}$ (Oxoid, Great Britain; Bioveta, Czech Republic). Suspensions corresponding to the McFarland turbidity standard no. 1 and subsequent dilutions in saline were prepared to achieve the target inoculum concentration. In the first experiment, suspension of a concentration of about $4.5 \mathrm{log}$ cells $/ \mathrm{ml}$ was used, in the subsequent experiments the concentration was progressively decreased to $3 \log , 2 \log$ and $1 \log$ cells $/ \mathrm{ml}$.

Inoculation, packaging, storage

Chicken legs were placed individually into sterile trays and their surface inoculated with bacterial suspension $(0.5 \mathrm{ml} /$ piece) spread by a sterile curved glass rod. Each tray was wrapped in AMILEN foil (Verpackungen 
GmbH, Germany) (PA/PE $20 \mu \mathrm{m} / 60 \mu \mathrm{m}, \mathrm{O}$, permeability $50 \mathrm{~cm}^{3} \cdot \mathrm{m}^{-2}$ at $24 \mathrm{~h} 23{ }^{\circ} \mathrm{C} 75 \%$ r.h., CO, permeability $150 \mathrm{~cm}^{3} \cdot \mathrm{m}^{-2}$ at $24 \mathrm{~h} 23{ }^{\circ} \mathrm{C} 0 \% \mathrm{r}$.h., water vapour permeability $3.0 \mathrm{~g} \cdot \mathrm{m}^{-2}$ at $24 \mathrm{~h} 23{ }^{\circ} \mathrm{C} 85 \% \mathrm{r}$.h.). The bags were flushed with commercial gas mixtures $30 \% \mathrm{CO}_{2} / 70 \% \mathrm{~N}_{2}$ or $20 \% \mathrm{CO}_{2} / 80 \% \mathrm{O}_{2}$ (Linde Gas, Czech Republic). The samples in $30 \% \mathrm{CO}_{2} / 70 \% \mathrm{~N}_{2}$ were packed with a VacStar S223 packing machine (Switzerland), the samples in $20 \% \mathrm{CO}_{2} / 80 \% \mathrm{O}_{2}$ were packed with a Turbovac 320-ST-S packing machine (Netherlands) and stored at $3.1 \pm$ $0.3^{\circ} \mathrm{C}$ for 3 to $14^{2}$ days.

Microbiological examination

Samples were analysed on days 0 (after Salmonella inoculation and attachment), 3, 7, 10 and 14 of storage. Each chicken leg was transferred into a sterile polyethylene bag and rinsed in $100 \mathrm{ml}$ of buffered peptone water (Oxoid, Great Britain). The enumeration of Salmonella in rinses was performed by the tree-tube most-probablenumber (MPN) method described for Salmonella by Malorny et al. (2008). RVS broth and XLD agar were used (Oxoid, Great Britain) as the selective media. Numbers of Salmonella in $1 \mathrm{ml}$ of rinse were calculated with a Microsoft Excel 2003 computer program using the Thomas formula (Blodgett 2008) and adjusted to MPN per piece.

Statistical analysis

The Salmonella counts were converted to log MPN per piece for the purpose of statistical analysis. Statistical analysis was performed by a StatPlus 2008 Professional v. 5.2.5.0 computer program. With regard to the nature of data we used a Kruskal-Wallis ANOVA non-parametric test for comparison of days within one concentration and atmosphere and for comparison of the atmospheres. A level of $p<0.05$ was considered significant.

\section{Results and Discussion}

In addition to temperature and atmosphere composition, the survival and growth of Salmonella is influenced by several other factors, including $\mathrm{pH}$ and competitive microflora. Several authors have reported the inability of Salmonella Enteritidis to compete successfully with lactic acid bacteria (De Fernando et al. 1995; Nychas and Tassou 1996). When modelling the growth of $S$. Typhimurium DT104 on chicken meat with the presence of natural microflora, Oscar (2007) found that the initial concentration of Salmonella is an important factor in growth rate. The results of another study suggest that the generation time of various serotypes and even phagotypes of $S$. Enteritidis varies considerably at temperatures approaching the minimum growth temperature of Salmonella (Fehlhaber and Krüger 1998).

Salmonella survival on chicken legs is presented in Fig. 1 as log MPN Salmonella per piece (mean $\pm \mathrm{SD}$ ). This figure shows that throughout storage there was no remarkable increase or decrease in Salmonella counts for any of the concentrations and atmospheres used.

In respect of the statistical analysis there were no significant differences found between days of storage in an atmosphere of $20 \% \mathrm{CO}_{2} / 80 \% \mathrm{O}_{2}$ for any of the initial concentrations. In the atmosphere of $30 \% \mathrm{CO}_{2} / 70 \% \mathrm{~N}_{2}$ there were significant differences $(p=0.043)$ between days 7 and 10 of storage in experiment No. 1 (initial concentration $4 \log$ MPN Salmonella/piece) and between days 3 and $10(p=0.021)$ and 3 and $14(p=0.033)$ in experiment No. 3 (initial concentration $1.5 \log$ MPN Salmonella/piece). In experiment No. 4 (initial concentration $0.5 \log$ MPN Salmonella/piece) values from day 3 and 14 were significantly different $(p=0.047)$. We found no significant differences between the modified atmospheres.

Several researchers have investigated the influence of this atmosphere on spoilage microorganisms in poultry meat. In general, modified atmospheres with an elevated $\mathrm{CO}_{2}$ concentration slow the growth of typical aerobic microflora, which is replaced by more resistant microorganisms such as lactic acid bacteria and related species. However, members of the family Enterobacteriaceae also compose a substantial part of the microflora (Jiménez et al. 1997). Similarly Balamatsia et al. (2006) observed an increase in Enterobacteriaceae counts in raw poultry meat stored at $4{ }^{\circ} \mathrm{C}$. Studies on the survival of Salmonella spp. in an atmosphere of $30 \% \mathrm{CO}_{2} / 70 \% \mathrm{~N}_{2}$ are limited, but Sawaya et al. (1995) noted growth of Enterobacteriaceae on naturally contaminated chicken meat after 3 days of storage at $2{ }^{\circ} \mathrm{C}$ and in $30 \% \mathrm{CO}_{2} / 70 \% \mathrm{~N}_{2}$ with numbers increasing by 3 log cycles 


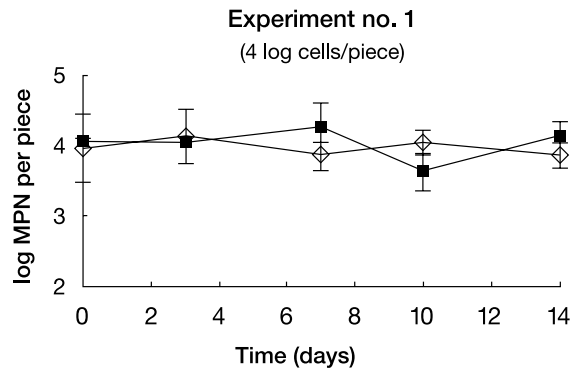

$-30 \%$ CO2 : $70 \%$ N2 $\diamond-20 \%$ CO2 : $80 \%$ O2

Experiment no. 3

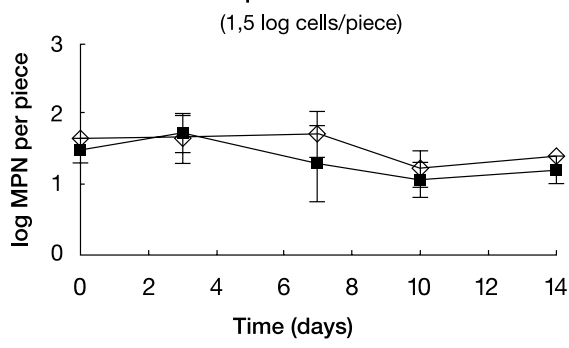

$-30 \%$ CO2 : 70\% N2 ๖ 20\% CO2 : $80 \%$ O2
Experiment no. 2

(2,5 log cells/piece)

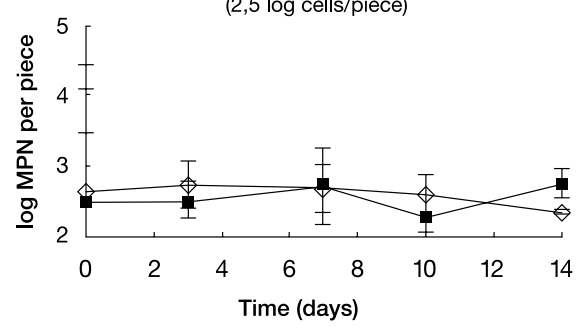

$-30 \%$ CO2 : $70 \%$ N2 $\diamond-20 \%$ CO2 : $80 \%$ O2

Experiment no. 4

(0,5 log cells/piece)

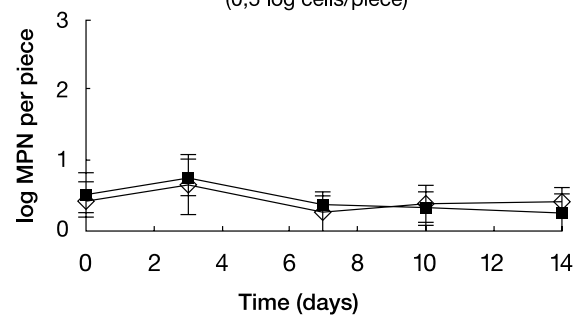

$-30 \%$ CO2 : $70 \%$ N2 $\diamond-20 \%$ CO2 : $80 \%$ O2

Fig. 1. Survival of Salmonella Enteritidis on chicken legs stored in modified atmospheres in relation to initial Salmonella concentration (mean $\pm \mathrm{SD}$ )

after 15 days. Salmonella spp. composed about $12 \%$ of Enterobacteriaceae members and the proportion remained constant throughout storage.

In the Czech Republic, mixtures of oxygen and carbon dioxide are widely used for whole poultry and poultry portion packaging. This modified atmosphere is also used by the poultry processing plant where the samples for this study were taken. Atmospheres composed of $25-90 \% \mathrm{O}_{2}$ and $15-80 \% \mathrm{CO}_{2}$ may be used, although $80 \% \mathrm{O}_{2} / 20 \% \mathrm{CO}_{2}$ is the most common gas mixture (McMillin 2008). High $\mathrm{O}_{2}$ atmospheres were developed for red meat packaging because the presence of oxygen maintains the myoglobin in its oxygenated form, thus giving the meat the bright red colour expected by consumers (Phillips 1996). The presence of oxygen is not essential for poultry, and in the case of turkey meat may even lead to differences in taste and smell (Floros and Matsos 2005). High levels of oxygen inhibit the growth of anaerobic bacteria, though it is also necessary to limit the growth of aerobic Gram-negative spoilage microorganisms (such as pseudomonads) with carbon dioxide (D’Aoust 1991).

The influence of high $\mathrm{O}_{2}$ atmospheres on Salmonella growth in chicken meat has been demonstrated by Nychas and Tassou (1996), who investigated the growth of S. enteritidis in artificially inoculated chicken breast stored at $3{ }^{\circ} \mathrm{C}$ in $20 \% \mathrm{CO}_{2} / 80 \% \mathrm{O}_{2}$. The initial concentration of $4.5 \mathrm{log} \mathrm{CFU} / \mathrm{g}$ did not change markedly throughout a 12 -day storage period.

Bacteriostasis of inoculated Salmonella cells by a combination of low storage temperature and carbon dioxide was also established in both modified atmospheres in our study. There was a significant decrease of Salmonella counts in an atmosphere of $30 \% \mathrm{CO}_{2} / 70 \% \mathrm{~N}_{2}$ after 10 or 14 days of storage, respectively, but this decrease was observed only in experiments with an initial concentration of Salmonella cells of $4 \log$ and $1.5 \mathrm{log}$ cells per piece. This 
could be caused for example by higher initial load of background microflora and its delayed development. What more, in spite of its importance for growth modelling and quantitative microbial risk assessments, Salmonella enumeration is not performed routinely. The MPN technique is particularly useful for enumeration of low concentrations of Salmonella cells. It is worthwhile noting that this method is extremely laborious (Malorny et al. 2008), so it is difficult to examine a large quantity of samples simultaneously, which negatively affects the power of the statistical tests.

Our results show that the initial concentration of Salmonella cells had no effect on their survival. We proved that low numbers of $S$. Enteritidis accompanied by natural microflora survive well on the surface of poultry stored at temperatures under $4{ }^{\circ} \mathrm{C}$ in both tested modified atmospheres, with a slightly better inhibition in the atmosphere with higher carbon dioxide concentration. In the case of more suitable growth conditions when a temperature abuse occurs in the commercial chain even products with low initial numbers of Salmonella cells can thus constitute a health risk for consumers.

\section{Vliv modifikované atmosféry na přežívání Salmonella Enteritidis PT 8 na povrchu chlazených kuřecích stehen}

Cílem naší práce bylo zjistit, zda i nízký počet salmonel v přítomnosti doprovodné mikroflóry přežije na kuřecích stehnech v průběhu skladování v atmosférách $30 \% \mathrm{CO}_{2} / 70 \% \mathrm{~N}_{2}$ a $20 \%$ $\mathrm{CO}_{2} / 80 \% \mathrm{O}_{2}$. Ve čtyřech pokusech bylo celkem 240 kusů kuřecích stehen naočkováno kmenem Salmonella Enteritidis, PT 8 (wildtype) v množství přibližně $4 \log , 2,5 \log , 1,5 \log$ a 0,5 log buněk na kus a skladováno ve vybraných modifikovaných atmosférách po dobu 14 dní. Počty salmonel byly stanovovány metodou Most Probable Number (MPN) 0., 3., 7., 10. a 14. den skladování). V průběhu skladování nedošlo v atmosféře $20 \% \mathrm{CO}_{2} / 80 \% \mathrm{O}_{2} \mathrm{k}$ významnému nárůstu ani poklesu počtu salmonel. U atmosféry $30 \% \mathrm{CO}_{2} / 70 \% \mathrm{~N}_{2}$ byl zaznamenán statisticky významný pokles 10., resp. 14. den skladování, který se však projevil pouze u pokusů s počáteční koncentrací salmonel $4 \log$ a 1,5 log buněk na kus. Prokázali jsme, že i nízké počty $S$. Enteritidis v přítomnosti doprovodné mikrofóry dobře přežívají na povrchu drůbeže při skladování při $3{ }^{\circ} \mathrm{C}$, a to v obou testovaných modifikovaných atmosférách. V př́ípadě vhodnějších růstových podmínek při porušení chladírenského řetězce tak mohou i výrobky s nízkým počátečním množstvím salmonel představovat pro konzumenta riziko nákazy.

\section{Acknowledgement}

This study was financially supported by IGA VFU (Grant number IGA 123/2008/FVHE) and MSM project No. 6215712402. The authors thank Dr. Karpíšková from the National Institute of Public Health in Brno who provided a suitable testing strain.

\section{References}

Balamatsia CC, Paleologos EK, Kontominas MG, Savvaidis IN 2006: Correlation between microbial flora, sensory changes and biogenic amines formation in fresh chicken meat stored aerobically or under modified atmosphere packaging at $4{ }^{\circ} \mathrm{C}$ : possible role of biogenic amines as spoilage indicators. Anton Leeuw Int $\mathrm{J} G$ 89: 9-17

Blodgett R 2008: Appendix 2. Most Probable Number from Serial Dilutions. Bacteriological Analytical Manual Online. Last modified February 2006. Accessed May 14, 2008. Available at: http://www.cfsan.fda.gov/ ebam/ bam-a2.html.

Bolder NM 2007: Microbial challenges of poultry meat production. World Poultry Sci J 63: 401-411

D'Aoust JY 1991: Psychrotrophy and foodborne Salmonella. Int J Food Microbiol 13: 207-216

De Fernando GDG, Nychas GJE, Peck MW 1995: Growth/survival of psychrotrophic pathogens on meat packed under modified atmospheres. Int J Food Microbiol 28: 221-231

EFSA 2009: The Community Summary report on Trends and Sources of Zoonosis and Zoonotical Agents in the European Union in 2007. The EFSA Journal: 14-94

FAO/WHO 2002: Risk Assessments of Salmonella in Eggs and Broiler Chickens. Food and Agriculture Organization of the United Nations, Rome, World Health Organization, Geneva, 306 p. 
S132

Fehlhaber K, Krüger G 1998: The study of Salmonella enteritidis growth kinetics using Rapid Automated Bacterial Impedance Technique. J Appl Microbiol 84: 945-949

Floros JD, Matsos KI 2005: Introduction to modified atmosphere packaging. In: HAN JH (Ed.): Innovations in Food Packaging. 1st ed. Elsevier Academic Press, London, pp. 159-171

Jiménez SM, Salsi MS, Tiburzi MC, Rafaghelli RC, Tessi MA, Coutaz VR 1997: Spoilage microflora in fresh chicken breast stored at $4^{\circ} \mathrm{C}$ influence of packaging methods. J Appl Microbiol 83: 613-618

Malorny B, Löfström C, Wagner M, Krämer N, Hoorfar J 2008: Enumeration of Salmonella bacteria in food and feed samples by real-time PCR for quantitative microbial risk assessment. Appl Environ Microb 74: 12991304

McMillin KW 2008: Where is MAP going? A review and future potential of modified atmosphere packaging for meat. Meat Sci 80: 43-65

Mead GC 2004: Current trends in he microbiological safety of poultry meat. World Poultry Sci J 60: 112-118

Nychas GJE, Tassou CC 1996: Growth/survival of Salmonella enteritidis on fresh poultry and fish stored under vacuum or modified atmosphere. Lett Appl Microbiol 23: 115-119

Olsen JE, Brown DJ, Madsen M, Bisgaard M 2003: Cross-contamination with Salmonella on broiler slaughterhouse line demonstrated by use of epidemiological markers. J Appl Microbiol 94: 826-835

Oscar TP 2007: Predictive models for growth of Salmonella typhimurium DT 104 from low and high initial density on ground chicken with a natural microflora. Food Microbiol 24: 640-651

Phillips CA 1996: Review: Modified Atmosphere Packaging and its effects on the microbiological quality and safety of produce. Int J Food Sci Tech 31: 463-479

Rasschaert G, Houf K, De Zutter L 2007: Impact of the slaughter line contamination on the presence of Salmonella on broiler carcasses. J Appl Microbiol 103: 333-341

Sawaya WN, Elnawawy AS, Abu-Ruwaida AS, Khalafawi S, Dashti B 1995: Influence of modified atmosphere packaging on shelf-life of chicken carcasses under refrigerated storage conditions. J Food Safety 15: 35-51 